This is an electronic reprint of the original article. This reprint may differ from the original in pagination and typographic detail.

Author(s): Rautiainen, Matti; Kostiainen, Emma

Title: $\quad$ Finland : Policy and Vision

Year: $\quad 2015$

Version:

Please cite the original version:

Rautiainen, M., \& Kostiainen, E. (2015). Finland : Policy and Vision. In T. Corner (Ed.), Education in the European Union : Pre-2003 Member States (pp. 91-108).

Bloomsbury Academic.

All material supplied via JYX is protected by copyright and other intellectual property rights, and duplication or sale of all or part of any of the repository collections is not permitted, except that material may be duplicated by you for your research use or educational purposes in electronic or print form. You must obtain permission for any other use. Electronic or print copies may not be offered, whether for sale or otherwise to anyone who is not an authorised user. 


\title{
Finland: Policy and Vision
}

\author{
Matti Rautiainen and Emma Kostiainen
}

\begin{abstract}
Finland's educational history can be divided into three periods. The first started in the Middle Ages when formal schooling began to develop in association with the church. The second started in the 17th century when Christian popular education was extended to include, in principle, the entire population. The third change was in the 19th century when the educational system significantly expanded to encompass not only basic education but also higher education and adult education.
\end{abstract}

The past decade has been very successful for Finland, at least according to international assessments measuring school learning outcomes (such as PISA and TIMMS). At the end of November 2012 Finland's education system was ranked the best in the developed world according to a survey carried out by the education company Pearson. What are the reasons for these results? In particular two significant trends underlie them. Firstly, the way the position of education has been shaped in Finnish society and, secondly, the organization of school and teacher education from the 1970s on.

Although the history of Finnish education can be regarded as a success story (especially during recent decades), the challenges for the future are huge. Society is changing rapidly and at the moment the 'hot' issues from pre-education to higher education are similar: what are the aims of education and what is ICT's role in education.

In this chapter we will first present the history of education in Finland. In the second part the focus is on the contemporary system and in the third we discuss the future of education in Finland.

\section{The period before the 1970s reform}

As stated, formal schooling began to develop in Finland in the Middle Ages in association with the church. The first school, the cathedral school in Turku, was founded in 1276 and its aim was to educate priests to serve the Catholic Church. Basic education affecting the entire population began hundreds of years later. In the 17th century Christian popular education was extended to include, in principle, the entire population. The starting point for the contemporary system, which also initiated the modern period of education, was the formation of a civic society in the 19th century when the entire educational system significantly expanded to encompass not only basic education but also higher education and adult education.

Before the 1850s the Finnish educational system was disjointed. Popular education was mainly organized and supervised by local clergy. Its aim was to teach the common people Christianity, reading and occasionally also writing. Although the church arranged various types of parish and municipal schools, part of the people still received instruction from their parents or other relatives or neighbours. (Laine and 
Laine 2010; Kuikka 1997). Higher education was provided at the beginning of the 19th century at Turku Cathedral School, a few trivial schools (i.e., teaching the trivium) and pedagogiums (i.e., grammar schools), and at a university (Turku Academy), which was transferred from Turku to Helsinki in 1828. Its name was changed to the Imperial Alexander University (from 1919, the University of Helsinki). Swedish and Latin were the dominant languages of instruction in such schools, and it was not until 1923 that Finnish became a teaching language at university.

The 1850s-1860s were an especially important period. In 1858 the development of basic education was affected by Tsar Alexander II's proclamation that in future primary schools could be founded with state support. Earlier, school funding had depended mainly on parishes, congregations and private financers. After the proclamation, the reform of primary education began in a spirit of liberalism. Under the direction of Uno Cygnaeus a new primary school system was planned and this included the development and organization of teacher education by means of teachers colleges. The 1866 primary school decree ratified the system. (Valtonen and Rautiainen 2012.)

The first teacher education college was founded in Jyväskylä in 1863, training both men and women teachers. In the 19th century and the first half of the 20th century teachers colleges were set up in various parts of Finland. Their creation was an important step in developing the new primary school. Also the first Finnish-language girls schools were founded in 1860s.

Nevertheless, a lot of children grew up without schools. It took decades to construct a comprehensive primary school network across Finland and to ensure that all schools had qualified teachers. At the beginning of the 20th century, Finland's educational system had assumed its basic form, which endured until the turn of the 1960s and 70s. Additionally the Finnish law on compulsory education was passed relatively late, in 1921. According to the law, general compulsory education was to be implemented even in the most isolated communities by the end of 1937. (Valtonen and Rautiainen 2012.)

The $19^{\text {th }}$ century was also a pioneering phase in vocational education and training. Agriculture, health care, business, industry and other fields increasingly needed more professionals, especially after 1879, when some restrictions on business and enterprise were expunged in accordance with an act passed by Alex III.

Until 1918, when Åbo Academi was founded for Swedish-speakers, the only university was in Helsinki. Before this, between 1640-1822, it was located in Turku, and was transferred to Helsinki in 1828 because of Helsinki's position as the new capital of Finland. The modern university network was established in Finland during the age of independence. Eight new universities were founded between 1920-1979 and the network covered the whole country.

\section{Education as a basis of the welfare state}

The primary school was the product of an agrarian society and its subject contents 
were largely planned to meet the needs of local peasant communities. After the Second World War Finnish society was influenced by many structural changes, including rapid changes in population structure and those affecting social and economic life. These also created the need for reforms to the educational system.

Egalitarianization, for example, was slow. Education in Finland remained strongly segregated on the basis of both gender and social status until the basic school reform at the turn of the 1960s and 70s (Valtonen and Rautiainen 2012; Rinne and Kivirauma 2003).

The system of basic education needed reforming in the 1960s. The hundred-year-old primary school system had reached its end and a thorough reform was initiated. In this reform both basic education and teacher education changed in Finland. Compulsory basic education for all was extended to nine years, after which pupils chose either upper secondary school or vocational education. The transition to the new basic school was carried out in stages beginning in 1972. The 1971 decree on teacher education transferred teacher education to the universities and from the end of the 1970s qualification as a class teacher has required a higher university degree, a Master of Education.

Figure 1. The Finnish educational system in 2011

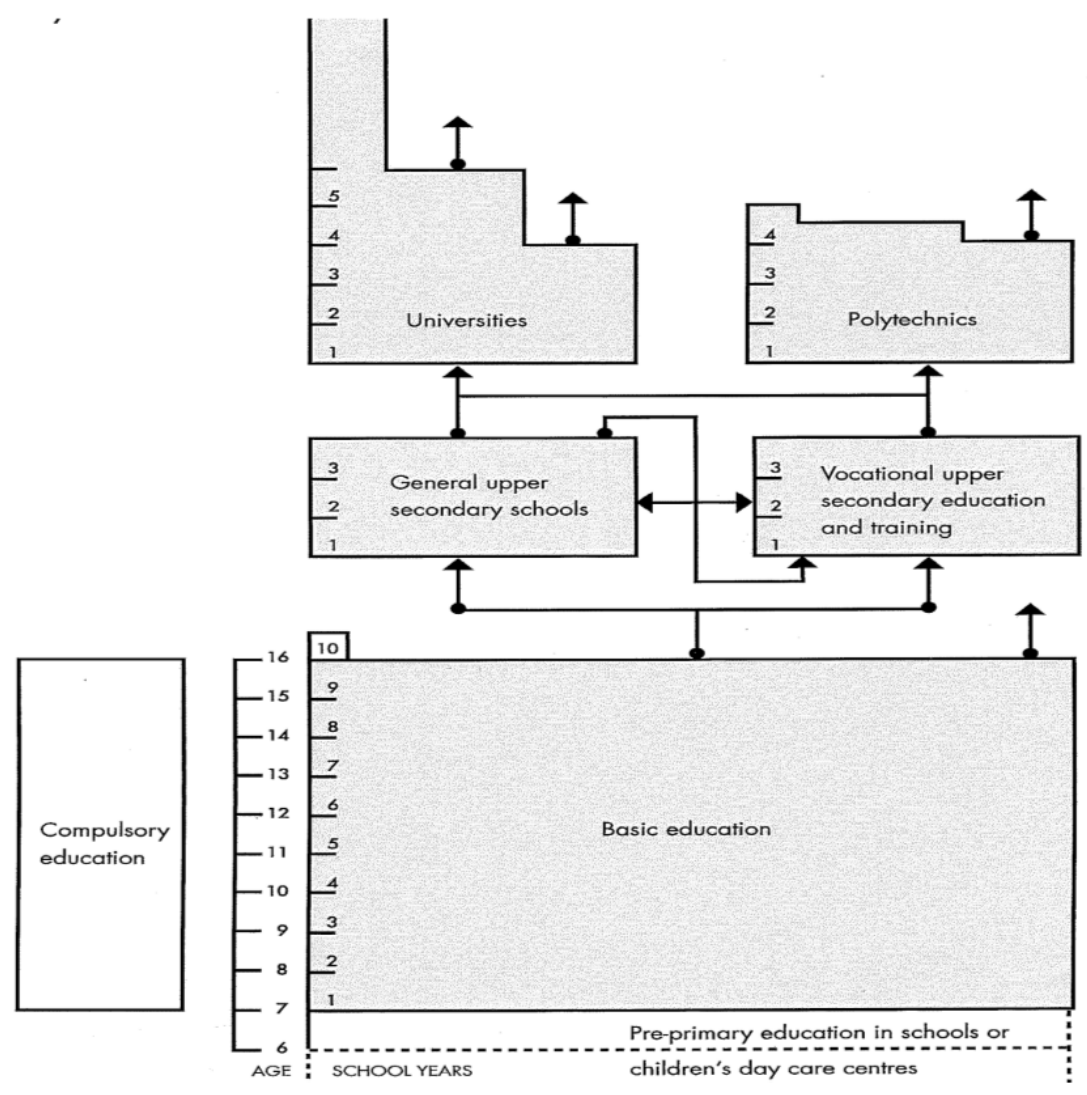

Source: National Core Curriculum for Upper Secondary Education 2003, p. 3.

Along with the reform, a new grammar-school oriented and subject-based way of 
thinking spread into school. Practical subjects were obliged to make way for academic studies and instead of civic skills schoolwork began to prepare pupils for universitystyle working. The reform also meant that more emphasis than earlier was placed in school on the study of facts. In practice this has meant an increase in objective knowledge and a reduction in the type of education and teaching intended to focus on the subjectivity of the person being educated. In other words, the basic school attached greater importance than the primary school to knowing a ready-made, generally accepted subject area, which was the goal of knowledge-based, objectivity-seeking subjects. Thus, the skill-based subjects, which were thought to engender independence, self-reliance, autonomous thinking, evaluative skills and ethicalness, became the poor relatives (e.g. Varto 2005).

The basic school reform also resulted in a clear content change in the educational ethical thinking of the school. Whereas in the 19th century sense of community dominated school education in the form of socialization, with ethical education concentrating on features of individual character, the prevailing premise of basic school education in the 20th century is individuality. By the end of the 20th century at the latest, the national quest for socialization had disappeared from Finnish educational policy to be replaced by a strong development of individualization which emphasized the individual's moral responsibility only to him or herself (Launonen 2000, pp. 3023). With these changes school made a significant move in the direction of individualcentredness. These above mentioned trends were naturally reflected in teacher education.

Over the past fifty years, the following three conceptions of school (Table 1) have appeared in the discussion of the Finnish school system (Suoranta 2003, pp. 137 138):

Table 1. Three school realities

\begin{tabular}{|l|l|l|l|}
\hline & Discipline school & Competition school & Cooperation school \\
\hline $\begin{array}{l}\text { Sociopolitical } \\
\text { dimension }\end{array}$ & $\begin{array}{l}\text { Discipline } \\
\text { Manners } \\
\text { Traditional values } \\
\text { Nostalgia }\end{array}$ & $\begin{array}{l}\text { Working-life bias } \\
\text { Entrepreneurship } \\
\text { Individualism }\end{array}$ & $\begin{array}{l}\text { Communality } \\
\text { Fairness } \\
\text { Hope }\end{array}$ \\
\hline $\begin{array}{l}\text { Pedagogical } \\
\text { dimension }\end{array}$ & $\begin{array}{l}\text { Teacher-led } \\
\text { Division } \\
\text { into subjects }\end{array}$ & $\begin{array}{l}\text { Constructivism } \\
\text { Individual learning }\end{array}$ & $\begin{array}{l}\text { Collaborativeness } \\
\text { Problem-derived }\end{array}$ \\
\hline
\end{tabular}

Source: Suoranta 2003, pp. 137-138.

The discipline school is based on established teaching curricula which are implemented in school as standard subjects according to strict and defined study programmes. The discipline school is characterized by its mass form, its closed introvertedness and formal classroom teaching. In the competition school these are replaced by individualism, openness and multimodal teaching. Even though the primary school cannot unambiguously be called a discipline school nor the basic school a school of the individual, the change from discipline school to individual school is a change from primary to basic school. In contrast, those features linked to the cooperation school are only just emerging as a part of school reality and the 
change is slow because the issue relates to a phenomenon that in practice is difficult to realize. Whereas genuine and successful cooperation is generally spontaneous, voluntary and development-oriented, enforced cooperation often produces a travesty of the intended goal (e.g., Hargreaves 1994; Sahlberg 1996).

\section{The Finnish educational system in the third millennium}

More than forty years have passed since the reform of basic education in Finland. According to international assessments measuring the learning outcomes of school, the results are in global terms extremely good. Finland has achieved especially good results in the PISA and TIMMS studies, which measure linguistic and mathematical abilities. In consequence, Finland's educational system has risen to become a focus of international interest, attracting educational experts from around the globe seeking reasons for the good results.

The reasons behind the success in international surveys are various. Children's opportunities to study and learn are quite equal. There is a strong supporting system in the school meeting the needs of special education. Teachers are highly qualified (MA level) and their pedagogical autonomy and freedom is high. Finland is also a very homogeneous culture even if the biggest cities are more multicultural than they were ten years ago. Finnish society also has a very strong belief in education and great confidence in teachers’ professionalism. (Välijärvi et al. 2007.)

Figure 2. Proportions of population with post-comprehensive level qualifications by age group in 1970, 1990 and 2011.

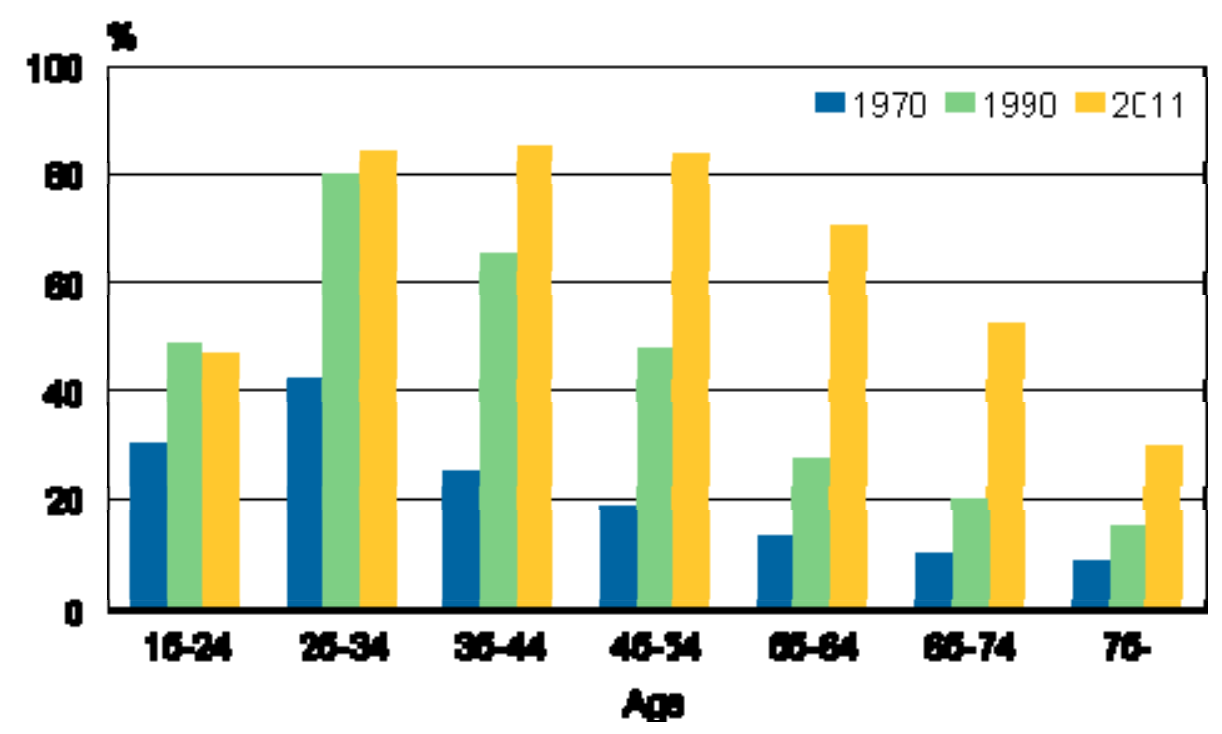

Source: Statistics Finland; Education.

http://www.stat.fi/til/vkour/2011/vkour_2011_2012-12-04_tie_001_en.html.

The statutory age for starting school in Finland is 7 years and pupils normally go to the nearest school regardless of the social status of the pupil's family. Schools are organized by municipality but are partly financed by the national government. Compulsory basic education consists of 9 grades. In school, the boundaries for the 
educational and intellectual goals of school are drawn by the class and subject teacher system. Even though Finland has a uniform basic school, the education of teachers remains clearly differentiated. Class teachers study education as a major, subject teachers as a minor, and the studies of these two groups hardly coincide at all during teacher education. In school the borderline between lower and upper school traditionally lies between class 6 and class 7. In present-day school it is not unusual for a class teacher to have lessons in the upper school (classes 7-9) and a subject teacher in the lower school (classes 1-6). Underlying the system is naturally the idea of increasing the intellectual content of study according to the number of years at school. Where school begins without subject differentiation, by the end of lower school it has already become tightly segmented around subjects. Schools are very similar in Finland, regardless of their location. There are a few private schools, such as Rudolf Steiner schools, where the emphasis is on alternative pedagogical principles.

Figure 3. Direct transition to further studies of those completing the 9th grade of comprehensive school 2005 - 2011 (\%)

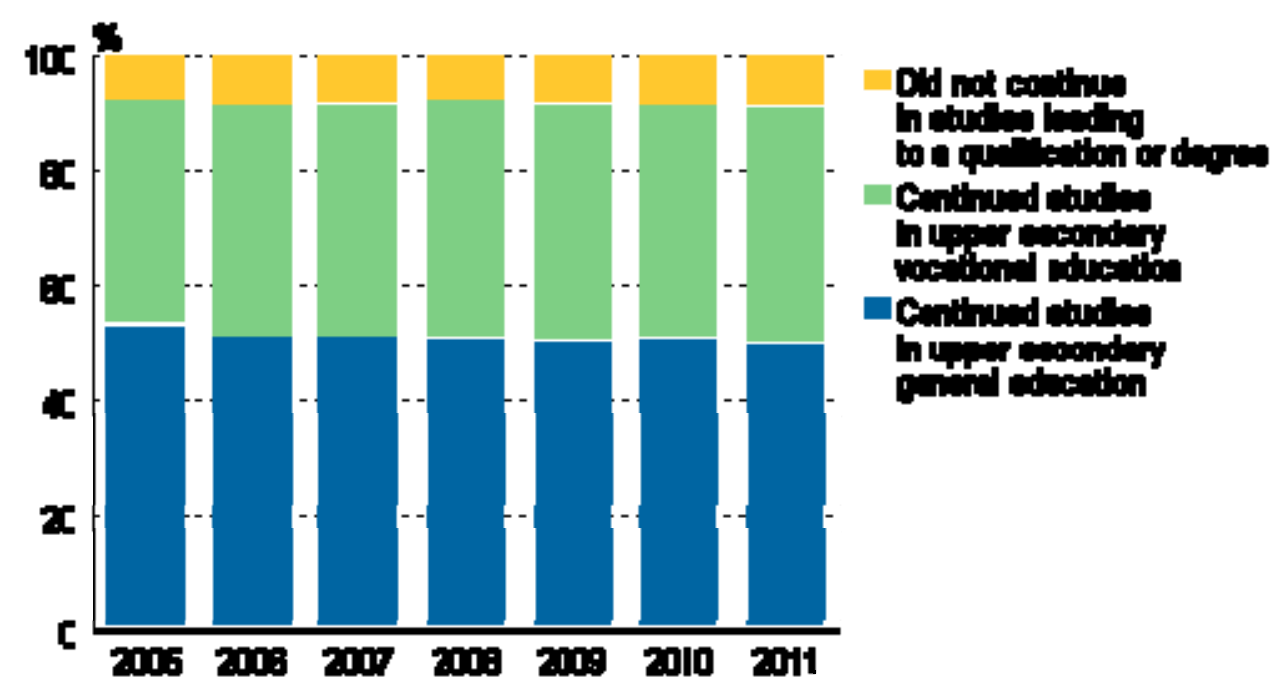

Source: Statistics Finland; Education.

http://www.stat.fi/til/khak/2011/khak_2011_2012-12-13_tie_001_en.html

Autonomy and pedagogical freedom are very important aspects of teacher identity in Finland. There is a prevailing social confidence in that the child will receive the same education regardless of school. This confidence is placed above all in the system and in teachers, whose professional skill is trusted. In the school culture itself, this trust is manifested as the considerable pedagogical autonomy of the teacher, with his or her work not subject to any supervisory or control mechanism. For example, in the early 1990s, government control of school textbooks was ended. Furthermore, the basic school has no nation-wide system of evaluation that applies to all schools. Assessment is done by the teacher who follows final-assessment criteria for the mark of 8 as defined in the National Core Curriculum for Basic Education. Naturally, this has its critics. Since assessment is in the hands of the teacher, some people regard the system as unfair, for example, from the viewpoint of applying for further studies. 
The ideal goals set up for the basic school were translated into concrete action and into an operational culture where the primary emphasis was placed on achievement of the learning goals set for school subjects. The objectives set for the work of the primary school were by nature ethically-loaded value objectives which gave a direction to schoolwork. In addition, they focused on teaching rather than learning. The basic school brought about four changes in the discussion of goals and objectives: 1) An objective-oriented focus on learning, 2) learning is seen as something broadly based and of a high level, and not as learning of basic civic skills and attitudes, 3) objectives are expressed precisely in the form of the learning of an individual pupil, and 4) the most important measure of successful school operation is achievement of the objectives set (Simola 1995, p. 95). The same change also took place in teacher education.

It is clear then that, with the concentration of activity on achievement of cognitive objectives set for individual subjects, Finnish children also perform well in evaluation studies measuring this. If the focus is shifted from factual knowledge to attitudes and particularly to participatory culture, Finland finds itself among the tail-enders: young people are rarely interested in politics, or indeed any social activity, e.g., participating in the activities of their community (Suoninen, Kupari and Törmäkangas 2010). The same result also emerged from a joint Finnish-German study that compared the social participation of Finnish and German young people (Feldmann-Wojtachnia et al. 2010). The Finnish school, however, has two faces. In the shadow of those good learning outcomes there lurks a democratic deficit in school and a lack of school wellbeing amongst children (Rautiainen and Räihä 2012).

This means there is a gap between the aim and practice of basic education, because the development of a democratic society is one of the key objectives in the National Core Curriculum for Basic Education:

"Basic education must provide an opportunity for diversified growth, learning, and the development of a healthy sense of self-esteem, so that the pupils can obtain the knowledge and skills they need in life, become capable of further study, and, as involved citizens, develop a democratic society.” (National Core Curriculum for Basic Education 2004, p. 12).

One reason for this tension is the radical democratic experiment in the early 1970s. In the beginning of the 1970s school councils became highly politicized in the 8-year grammar schools and this was quite a traumatic period for teachers. The experiment was quietly ditched towards the end of the 1970s and schools became islands where people were careful not to talk about politics, in other words, not to take a stand on contentious issues. With the introduction of the comprehensive school, assessment of learning moved more vigorously towards evaluation of how well individual pupils achieved the objectives set for each subject. Thus, by the start of the 1980s, schools had become socially neutral places (Rautiainen and Räihä 2012; Kärenlampi 1999). The physical structure of schools, such as their space allocation, was a direct reflection of this state. Apart from the corridors and entrance halls pupils had no space of their own for meeting or spending time (e.g. Tolonen 2001). During the last fifteen years there have been numerous different projects with the aim of democratizing schools, but so far little has happened. For example pupils' unions do not have enough power in school decision-making. They are still more like organizations 
whose function is to arrange celebrations.

International assessment studies have shown that the differences between Finnish schools are small; in other words, the basic school's principle of equality has been realized well. Although teachers in the basic school enjoy a high social status and it is very popular to apply especially for class teacher courses, it has occasionally been difficult to find qualified teachers for remote areas or the capital region. Increasingly multicultural cities and continuing rural depopulation confront school with huge challenges.

After basic education students continue to vocational education and training or general upper secondary school. Upper secondary school concludes with matriculation, which is the only national examination in the whole educational system. Matriculation gives eligibility for higher education studies.

Figure 4. Direct transition to further studies of those passing the matriculation examination 2005 - 2011 (\%)

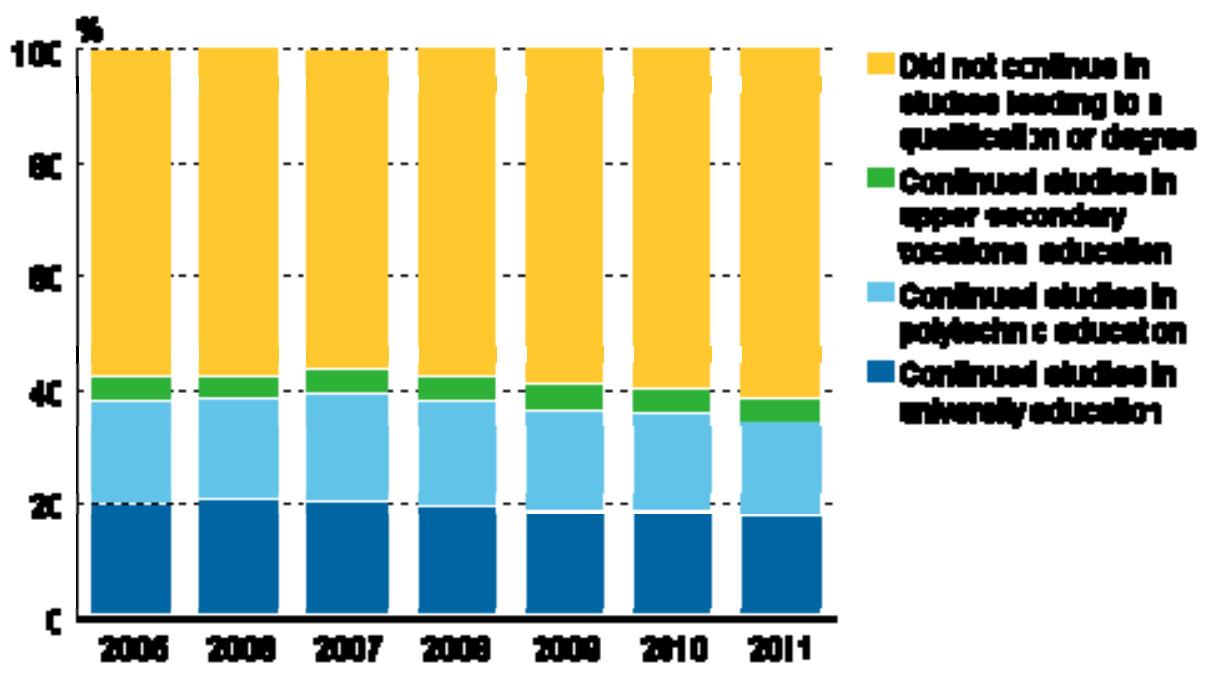

Source: Statistics Finland; Education.

http://www.stat.fi/til/khak/2011/khak_2011_2012-12-13_tie_001_en.html

During recent decades there have been huge changes in vocational education. The 1990s saw the foundation, alongside university-level institutions, of polytechnics, which were made up of college-level vocational institutions and offered a lower form of higher education. In 1991-1992 the first polytechnics started on a trial basis and the first nine polytechnics were made permanent in 1996. By 2000 all polytechnics were operating on a permanent basis. At the start of the present decade there were over 20 polytechnics. College-level vocational education began in the 19th century, mainly in the form of agricultural, business and commercial and technical training. It expanded in the 20th century, especially after World War II. Lower vocational education is offered by vocational schools, whose foundation also began in the 19th century and whose number significantly increased until the 1970s (Klemelä 1999). 
The largest fields in initial vocational education are Technology and Transport (approx. 36\%), Business and Administration (19\%) and Health and Social Services (17\%). The other fields are Tourism, Catering and Home Economics (13\%), Culture (7\%), Natural Resources (6\%) and Leisure and Physical Education (2\%). Around 50000 new students begin their studies in initial vocational training every year (Ministry of Education and Culture 2013).

The new Universities Act in 2010 was the biggest university reform since 1640. With the reform the autonomy of universities was extended by giving them an independent legal status, either as public corporations or as foundations. Also the universities' management and decision-making system was reformed by giving them larger economic and administrative autonomy. Nevertheless, the main assignment education, research, and regional interaction - remains unchanged. One of the main objectives of the reform is to facilitate operation in an international environment. In addition, the aim is, for example, to improve universities' ability to react better to changes in the operational environment, diversify their funding base, direct resources to top-level research and strengthen universities' role within the system of innovation. (Ministry of Education and Culture 2013; see also Hautamäki 2010, 40.)

According to Statistics Finland, a total of 169,000 students attended university education leading to a degree in 2012. The amount is high, and the Ministry of Education and Culture is trying to decrease it. Teacher education is one of the most popular fields at the higher education level.

Figure 5. University students by fields of education (Educational Administration's classification 1995) in 2012

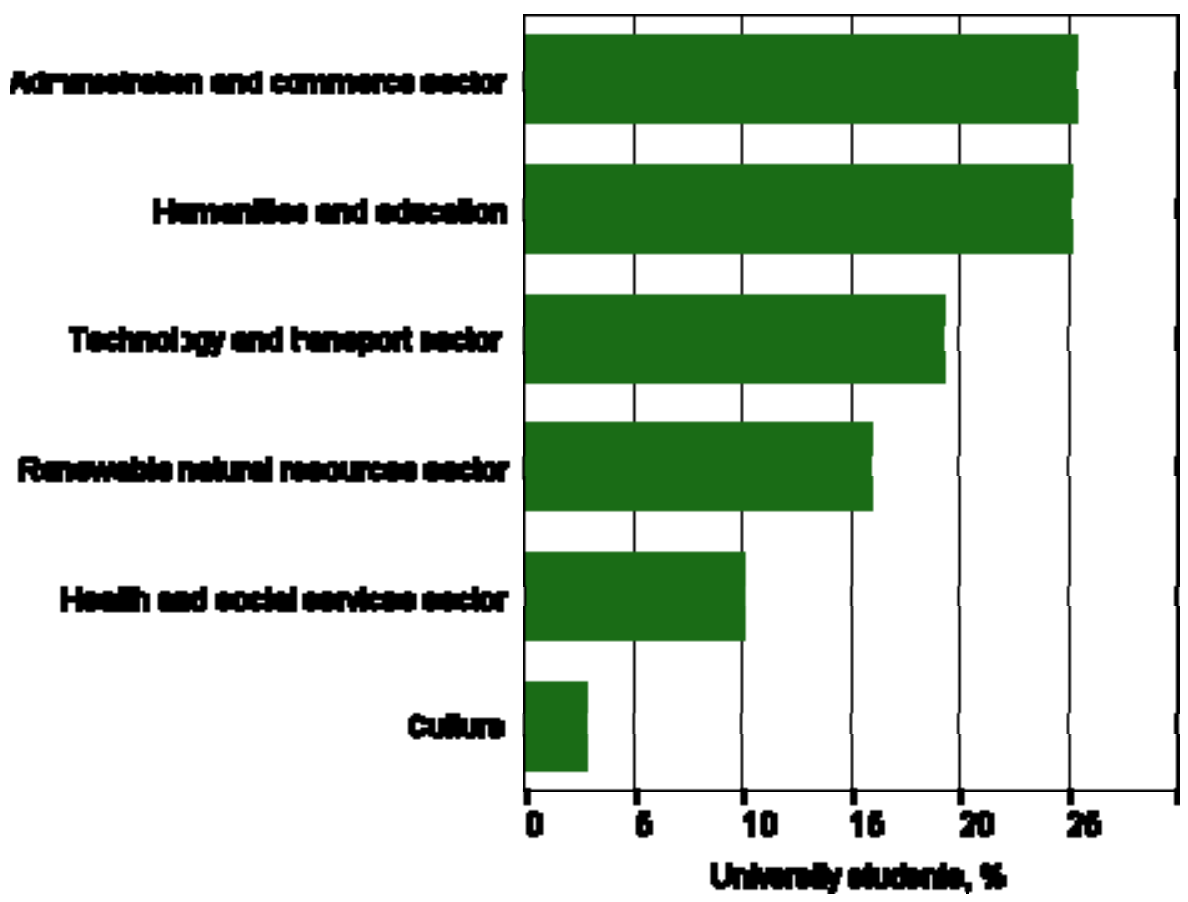

Source: Statistics Finland; Education. http://www.stat.fi/til/yop/index.html 


\section{Towards the future}

In the twenty-first century, the period of quantitative growth in education lies far behind and there is powerful pressure to close and combine educational institutions and to reduce overlap. Underlying this, on the one hand, is the need to make financial savings, and on the other, the view that by reforming its educational system Finland can improve its competitiveness as a nation. Despite the changes, one unifying feature characterizes all of the stages in Finland's educational history since the second half of the nineteenh century: a strong belief in the power of education. This is characteristic of future thinking, too.

As described earlier the basic elements in Finland's educational system are structured successfully. The challenges of future development concern more the regeneration of practices and attitudes concerning an 'already excellent' education. The future of education needs new ways of thinking and inspiring visions (Sahlberg 2011).

One clear advantage of the Finnish educational system rests on the fact that both its strengths and weaknesses are treated critically and the system is the subject of investigation. Especially success in PISA has increased the pressure for constant vigilance in the arena of education. Although the present system is ranked high in international assessments, the future is pursued in a way that both the obvious and hidden contradictions, contrasts and tensions in the educational system are seen and brought out. These tensions must be seen rather as an input of development, than a barrier or obstacle to change.

When considering the future of education in Finland the following tensions generate continuums that must be the object of continuous and critical study and analysis.

From static state to dynamic agility. Education has to take an active role in relation to change in society. When education rests on firm foundations there is an opportunity to make various experiments. These experiments are not yet numerous but the tendency must be towards implementing innovative pilots at many levels within educational institutions. Especially the most courageous experiments must produce research-based knowledge and experiences. For example the futurelaboratories built in educational settings are seen as concrete steps towards the future.

Extending perspective from the present and near future to the long-term future. Development work in education needs on-going and open-minded vision work. When drawing up scenarios of future education the perspective must be on the long-term future (see e.g., Jääskelä, Klemola, Kostiainen and Rautiainen 2012; Wilenius and Kurki 2012). By extending the future perspective far enough ahead it is possible to disengage oneself from the present system where many solutions seem to be impossible and inconceivable. These far reaching scenarios offer a possibility to explore the "empty" phase between the current and the long-term future. In this liminal phase professionals are in a position where they have to test the boundaries of their thinking: what can be imagined to be possible? Research-based teacher 
education has a key role in educating future-oriented professionals who are capable of making changes in Finnish society.

The future of education also needs new ways of framing questions concerning education: What does the future school look or feel like? How are time and space perceived in the future school? What is the aim of future school? This also means a shift from a sense of security to risk taking as well as a shift from the familiar to the unknown. Visionary and ground-shaking ideas and questions are needed when envisioning the future of education. (Jääskelä et al. 2012.)

From conventional views of time and space to new ways of constructing time and space. Time and space constitute the framework of learning in formal educational settings. Existing spaces do not sufficiently support future learning. We must dare to think about time and space in a new and creative way. 'Space' in educational settings should be seen as consisting of physical, intellectual, social and emotional features. Also offering empty space - both physically and intellectually - is important. Seeing the 'void' as a resource gives time and space for fascination and enthusiasm. (Jääskelä et al. 2012.)

From non-participation to participation and involvement. As mentioned previously, schools do not have a strong participatory culture (Rautiainen and Räihä 2012). There is a need for education where the aim is on processes (explorative in nature) developing future schools as communities (Dewey 1966). Processes themselves are seen as both the method and object of learning. These processes include construction of networks with actors and stakeholders from different fields of society. Future schools and educational institutions are seen as dynamic communities that offer democratic, participative and collaborative spaces for creativity and learning. Learners themselves should be the active actors in constructing the best learning environments - whether more physical or virtual in nature - and the consequent participative culture. New technology and architecture have a key role in the construction of these communities. (Jääskelä et al. 2012.)

From structured systems to open systems. New learning environments supported by modern technology offer possibilities in complex problem solving and construction of shared knowledge and understanding that can radically change the nature of learning (see e.g. Häkkinen and Hämäläinen 2012). However, there is a considerable gap between students' actual capacity and experience in using ICT in informal settings and its pedagogical use and application in schools. Although the infrastructure and provision of ICT equipment as well as commitment to it at the level of school policies and strategies is close to the average of other EU countries, at present educational institutions in Finland are more conformists than forerunners in relation to ICT (Häkkinen, Silander and Rautiainen 2013; Survey of Schools: ICT in Education 2013).

In the long-term future the welfare - both social and economic - of future societies is an interwoven construction of various factors where especially education and 
development of modern technology play a crucial role. It is envisioned that the interplay of technology and its uses is an essential issue in futures research and that the actual challenge lies in understanding its future societal uses (Wilenius and Kurki 2012, p. 50).

\section{REFERENCES}

Dewey, J. (1966), Democracy and Education. New York: The Free Press.

Feldmann-Wojtachnia, E., Gretschel, A., Helmisaari, V., Kiilakoski, T., Matthies, AL., Meinhold-Henschel, S., Roth, R. and Tasanko, P. (2010), Youth Participation in Finland and in Germany - Status Analysis and Data Based Recommendation. (http://www.nuorisotutkimusseura.fi/sites/default/files/verkkojulkaisut/Youth\%20participation\%20in\% 20Finland\%20and\%20in\%20Germany.PDF) accessed June 17, 2013.

Hargreaves, A. (1994), Changing Teachers, Changing Times. Teachers' Work and Culture in the Postmodern Age. New York: Teachers College Press.

Hautamäki, A. (2010), Sustainable innovation. A New Age of Innovation and Finland's Innovation Policy. Sitra Reports 87.

(http://www.kestavainnovaatio.fi/sustainableinnovation_book.pdf) accessed June 19, $\underline{2013 .}$

Häkkinen, P. and Hämäläinen, R. (2012), Shared and personal learning spaces: Challenges for pedagogical design. Internet and Higher Education 15, (4), 231-236.

Häkkinen, P., Silander, T. and Rautiainen, M. (2013), Kohti tulevaisuuden koulua ja uusia oppimisympäristöjä. [Towards the Future School and New Learning Environments], in P. Jääskelä, U. Klemola, M.-K. Lerkkanen, A.-M. Poikkeus, H. Rasku-Puttonen and A. Eteläpelto (eds), Yhdessä parempaa pedagogiikkaa. Interaktiivisuus opetuksessa ja oppimisessa. [Better Pedagogy Together. Interactivity in Teaching and Learning]. University of Jyväskylä: Finnish Institute of Educational Research, pp. 139-143.

Jääskelä, P., Klemola, U., Kostiainen, E. and Rautiainen, M. (2012), Constructing the Future School Community - The Scenario of an Interactive, Agency Building and Creative Learning Environment, in Conference Proceedings Volume 1 (The Future of Education Florence, Italy 7-8 June 2012). Milano: Simonelli Editore, pp. 175-178.

Klemelä, K. (1999). Ammattikunnista ammatillisiin oppilaitoksiin. Ammatillisen koulutuksen muotoutuminen Suomessa 1800-luvun alusta 1990-luvulle. [From trades to vocational colleges. The formation of vocational education in Finland from the early 1800s to the 1990s]. Turku: Turun yliopisto.

Kuikka, M. T. (1997), A history of Finnish education [translated by Käännöstoimisto Valtasana oy]. Helsinki: Otava.

Kärenlampi, P. (1999), Taistelu kouludemokratiasta. Kouludemokratian aalto Suomessa. [The Fight for School Democracy. The Wave of School Democracy in Finland]. Bibliotheca Historica 37. Helsinki: Suomen Historiallinen Seura [Finnish 
Historical Society].

Laine, E. M. and Laine, T. (2010), Kirkollinen kansanopetus. [Church popular teaching], in J. Hanska and K. Vainio-Korhonen (eds), Huoneentaulun maailma. [The world of the rule board]. Helsinki: SKS, pp. 258-306.

Launonen, L. (2000), Eettinen kasvatusajattelu suomalaisen koulun pedagogisissa teksteissä. [Ethical educational thinking in pedagogical texts in the Finnish school]. Jyväskylä studies in education, psychology and social research 168.

Ministry of Education and Culture. (2013), (http://www.minedu.fi/OPM/Koulutus/koulutuspolitiikka/Hankkeet/Yliopistolaitokse n_uudistaminen/?lang=en) accessed June 14, 2013.

National Core Curriculum for Basic Education 2004. (2004) Helsinki: Finnish National Board of Education. (http://www.oph.fi/english/sources_of_information/core_curricula_and_qualification_ requirements/basic_education) accessed June 12, 2013.

National Core Curriculum for Upper Secondary Schools 2003. (2003). Helsinki: Finnish National Board of Education. (http://www.oph.fi/download/47678 core curricula upper secondary education.pdf) accessed June 10, 2013.

Rautiainen, M. and Räihä, P. (2012), Education for Democracy: A Paper Promise? The Democratic Deficit in Finnish Educational Culture. Journal of Social Science Education, 11, (2), 7-23. (http://www.jsse.org/2012/2012-2) accessed June 19, 2013.

Rinne, R. and Kivirauma, J. (eds). (2003), Koulutuksellista alaluokkaa etsimässä. Matala koulutus yhteiskunnallisen aseman määrittäjänä Suomessa 1800- ja 1900 luvuilla. [In search of an educational underclass. Low-level education as a determiner of social status in Finland in the $19^{\text {th }}$ and $20^{\text {th }}$ centuries]. Turku: Suomen kasvatustieteellinen seura.

Ministry of Education and Culture. (2013), (http://www.minedu.fi/OPM/Koulutus/ammatillinen_koulutus/?lang=en) accessed June 15, 2013.

Sahlberg, P. (1996), Kuka auttaisi opettajaa. Postmoderni näkökulma opetuksen muutokseen yhden kehittämisprojektin valossa. [Who would like to help the teacher. A postmodern view of the change in teaching in the light of one development project]. Jyväskylän yliopisto. Jyväskylä Studies in Education, Psychology and Social Research 119.

Sahlberg, P. (2011), Finnish Lessons. What Can the World Learn from Educational Change in Finland? New York: Teachers College Press.

Simola, H. (1995), Paljon vartijat. Suomalainen kansanopettaja valtiollisessa kouludiskurssissa 1860-luvulta 1990-luvulle. [Keepers of plenty. The Finnish primary school teacher in the state school discussion from the 1860s to the 1990s]. 
Helsinki: Helsingin yliopiston opettajankoulutuslaitos.

Suoninen, A, Kupari, P and Törmäkangas, K. (2010), Nuorten yhteiskunnalliset tiedot osallistuminen ja asenteet. Kansainvälisen ICCS-tutkimuksen esituloksia. [The social knowledge, participation and attitudes of young people. Preliminary results of the international ICCS study]. Jyväskylän yliopisto: Koulutuksen tutkimuslaitos.

Suoranta, J. (2003), Kasvatus mediakulttuurissa. Mitä kasvattajien tulee tietää. [Education in media culture. What the educator should know]. Tampere: Vastapaino.

Survey of Schools: ICT in Education 2013. Benchmarking access, use and attitudes to technology in europe's schools. European Union. Final Study Report February 2013. (https://ec.europa.eu/digital-agenda/sites/digital-agenda/files/KK-31-13-401-ENN.pdf) ) accessed June 19, 2013.

Tolonen, T. (2001), Nuorten kulttuurit koulussa: ääni, tila ja sukupuolten arkiset järjestykset. [Youth Cultures in School: Voice, Space and Everyday Orders of the Sexes]. Helsinki.

Valtonen, H. \& Rautiainen, M. (2012), La educación finlandesa desde 1850 hasta el presente. ISTOR Revista de Historia Internacional, 12, 48, 129-160.

Varto, J. (2005), Koulun syytä etsimässä. Tiedon ja taidon erilaiset tehtävät kasvatuksessa. [In search of a reason for school. The different roles of knowledge and skill in education], in T. Kiilakoski, T. Tomperi and M. Vuorikoski (eds) Kenen kasvatus. Kriittinen pedagogiikka ja toisin kasvatuksen mahdollisuus. [Whose education. Critical pedagogy and the possibility of a different education.] Tampere: Vastapaino, pp. 197-216.

Välijärvi, J., Kupari, P., Linnakylä, P., Reinikainen, P., Sulkunen S., Törnroos, J. and Arffman, I. (2007), The Finnish Success in Pisa - And Some Reasons Behind It 2. Institution for Education Research. University of Jyväskylä. (http://ktl.jyu.fi/img/portal/8302/PISA_2003_screen.pdf) accessed June 19, 2013.

Wilenius, M.and Kurki, S. (2012), Surfing the sixth wave. Exploring the next 40 years of global change. University of Turku. Finland Futures Research Centre, eBOOK 10/2012. (http://www.utu.fi/fi/yksikot/ffrc/julkaisut/e-tutu/Documents/eBook_201210.pdf) accessed June 19, 2013. 